\title{
Anesthetics may modulate cancer surgical outcome: a possible role of miRNAs regulation
}

\author{
Masashi Ishikawa ${ }^{1,2^{*+}} \mathbb{D}$, Masae Iwasaki ${ }^{1,2+}$, Atsuhiro Sakamoto ${ }^{1}$ and Daqing $\mathrm{Ma}^{2}$
}

\begin{abstract}
Background: microRNAs (miRNAs) are single-stranded and noncoding RNA molecules that control posttranscriptional gene regulation. miRNAs can be tumor suppressors or oncogenes through various mechanism including cancer cell biology, cell-to-cell communication, and anti-cancer immunity.

Main Body: Anesthetics can affect cell biology through miRNA-mediated regulation of messenger RNA (mRNA). Indeed, sevoflurane was reported to upregulate miR-203 and suppresses breast cancer cell proliferation. Propofol reduces matrix metalloproteinase expression through its impact on miRNAs, leading to anti-cancer microenvironmental changes. Propofol also modifies miRNA expression profile in circulating extracellular vesicles with their subsequent anti-cancer effects via modulating cell-to-cell communication.

Conclusion: Inhalational and intravenous anesthetics can alter cancer cell biology through various cellular signaling pathways induced by miRNAs' modification. However, this area of research is insufficient and further study is needed to figure out optimal anesthesia regimens for cancer patients.
\end{abstract}

Keywords: MicroRNA, Anesthetics, Cancer, Anti-cancer immunity, Cell-to-cell communication

\section{Background}

Surgery is the frontline treatment of solid cancers worldwide. Over $60 \%$ of cancer patients require general anesthesia for primary surgical resection [1]. Unfortunately, most patients still die due to cancer recurrence following surgery [2]. Postsurgical death is the third most common type of death behind the death from cardiovascular disease and stroke and contributes to $7.7 \%$ of deaths globally [3] and most those patients are cancer suffers per se. Postoperative cancer recurrence often occurs in high

\footnotetext{
* Correspondence: masashi-i@nms.ac.jp

${ }^{\dagger}$ Masashi Ishikawa and Masae Iwasaki contributed equally to this work. 'Department of Anesthesiology and Pain Medicine, Graduate School of Medicine, Nippon Medical School, 1-1-5, Sendagi, Bunkyo, Tokyo 113-8603, Japan

${ }^{2}$ Division of Anaesthetics, Pain Medicine and Intensive Care, Department of Surgery and Cancer, Faculty of Medicine, Imperial College London, 369 Fulham Rd, London SW10 9NH, UK
}

malignancy of cancer cell phenotype but perioperative risk factors may also contribute to its recurrence. For example, surgical stress activates neural and inflammatory cellular signaling that can suppress anti-tumor immunity, increase cancer cell growth and their shedding into blood circulation, and promote cancer cell adhesion residence in remote organs, all of which contribute to tumor recurrence [4-6]. Anesthetics may be also a risk factor due to their direct immunomodulation or indirect cellular signaling effects [7]. Indeed, pre-clinical and retrospective studies indicated that some anesthetics such as inhalational agents may promote cancer cell growth, whereas others such as propofol and midazolam inhibit cancer cell growth and hence may be beneficial for cancer patients [8-10]. The molecular mechanisms behind these clinical findings are largely unknown.

\section{$\triangle B M C$}

(c) The Author(s). 2021 Open Access This article is licensed under a Creative Commons Attribution 4.0 International License, which permits use, sharing, adaptation, distribution and reproduction in any medium or format, as long as you give appropriate credit to the original author(s) and the source, provide a link to the Creative Commons licence, and indicate if changes were made. The images or other third party material in this article are included in the article's Creative Commons licence, unless indicated otherwise in a credit line to the material. If material is not included in the article's Creative Commons licence and your intended use is not permitted by statutory regulation or exceeds the permitted use, you will need to obtain permission directly from the copyright holder. To view a copy of this licence, visit http://creativecommons.org/licenses/by/4.0/ The Creative Commons Public Domain Dedication waiver (http://creativecommons.org/publicdomain/zero/1.0/) applies to the data made available in this article, unless otherwise stated in a credit line to the data. 
microRNAs (miRNAs) are single-stranded and noncoding RNA molecule with 20-25 nucleotides and participate post-transcriptional gene regulation of mRNA via mRNA degradation and translational repression. In human, there are more than 1500 miRNAs but their roles in normal and pathological cellular function remain yet to know. Previous study demonstrated that miRNAs modulate various cell biology, including cell differentiation, proliferation, apoptosis, embryonic development, stress response, stem cell renewal, and metabolism [11-15].

It has been suggested that anesthetics, can both positively and negatively influence on cancer surgical outcome through miRNA changes. Previous in vitro studies showed that inhalational and intravenous anesthetics have both pro- and anti-cancer effects through various pathways of cancer cell biology, anti-cancer immunity, and cell-to-cell communication via miRNA expression changes. In this review, the effects of anesthetics effects on cancer cell phenotyping changes via miRNA modulation will be narratively summarised; their other effects on cancer cell biology through other cellular signaling pathways have been well documented recently $[7,16,17]$ will be repeated again here.

\section{Main Body miRNA in oncogenesis}

One miRNA can have an average of more than 100 targets [18], and multiple miRNAs can affect the expression of a single transcript target [19]. The overview of mRNA regulation of miRNA is shown in Fig. 1. Thus, minor variations in miRNA expression may have crucial consequences for malignant transformation and cancer cell activity whilst miRNA alterations may involve in the initiation and progression of human cancer [20]. miRNAs also influence on numerous oncogenesis processes, such as cellular metabolism, differentiation, proliferation, cell cycle control, apoptosis and migration [21-23]. The role of miRNAs in chronic lymphocytic leukaemia patients was reported in 2002 [24], disclosing that miRNAs are associated with the occurrence and progression of various cancers. It is known that miR-133 regulates cancer cell apoptosis with suppression of caspase-9 [25] whereas miR-24 enables cancer cells to survive by

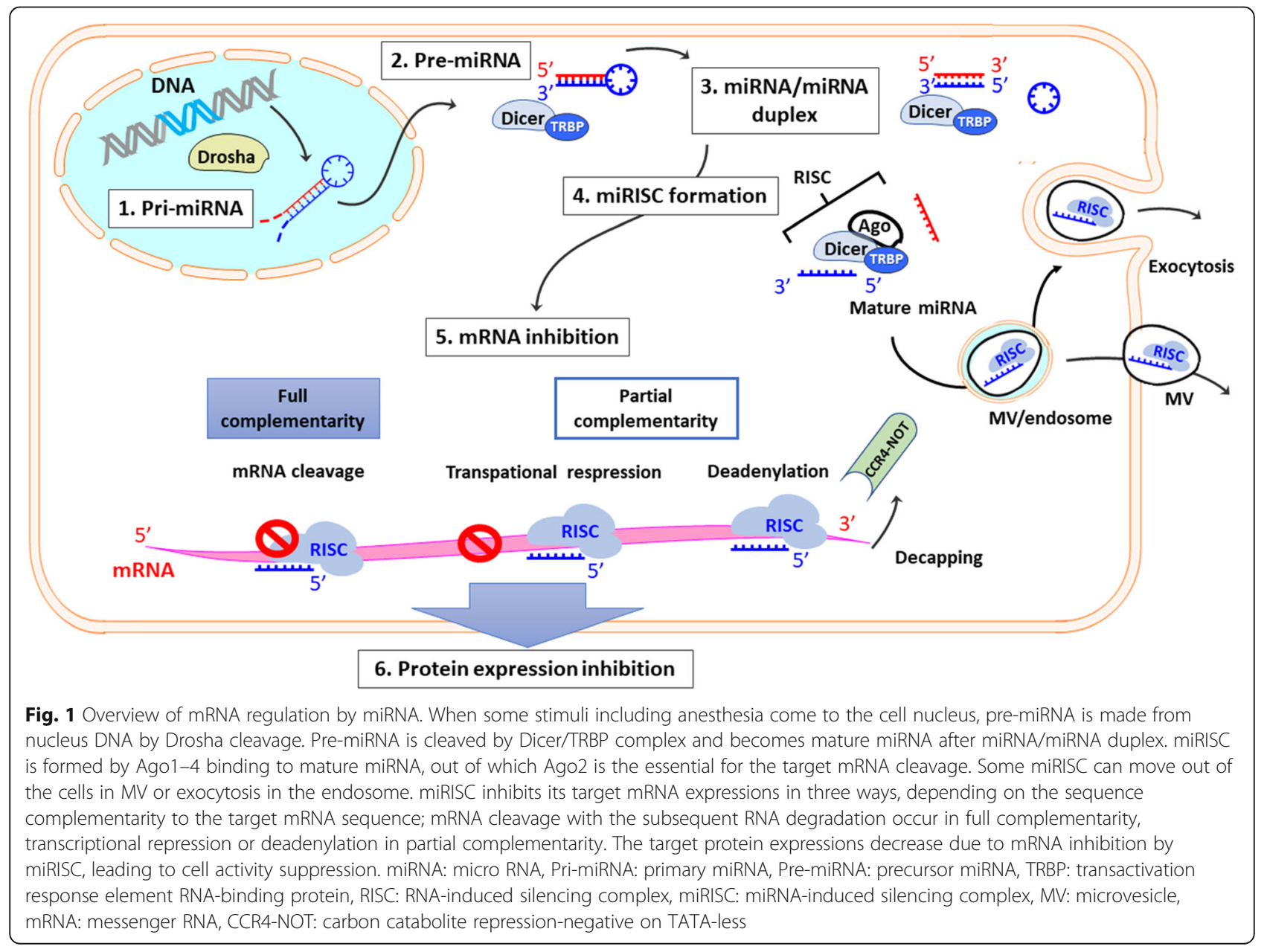


targeting X-linked inhibitor of apoptosis (XIAP) [26] which suppresses apoptosis by downregulation of caspases. miR-372 was reported to exert tumor-promoting roles and its upregulation was correlated with the tumor node metastasis stage in patients with hepatocellular carcinoma [27].

Previous studies indicated that these miRNAs could modulate cancer microenvironment or tumor transformation. miR-21 overexpression promoted tumorigenesis in prostate [28] and cervical [29] cancers. Also, miR-21 upregulation increased chemoresistance in lung adenocarcinoma [30], invasiveness and angiogenesis in renal carcinoma [31] and lymphoma [32]. miR-125a also modulated the chemo-sensitivity in breast cancer [33, 34], and promoted tumorigenesis of colon cancer [35]. miR-9 increased tumorigenesis, angiogenesis and metastasis in breast [36, 37], liver [38] and pancreas cancer [39] and squamous cell carcinoma [40]; in contrast, miR-9 was also reported to suppress angiogenesis and metastasis of melanoma [41], gastric [42] and nasopharyngeal cancers [43]. miR-455-3p enhanced invasiveness of breast cancer $[44,45]$, regulated the cell proliferation and migration of lung cancer [46], supressed tumorigenesis in prostate [47] and colon cancer [48, 49]. Clearly, different miRNAs have different roles in different cancers in terms of development and progression.

Early diagnosis of cancer is often difficult because of the poor sensitivity of current tumor markers but miRNAs may be expected to become early detection markers for tumors. Generally, when the pro-cancer miRNAs are highly expressed, the suppressor miRNAs show low expression. These dysregulated-miRNA expressions appear to be specific pattern of each cancer type. Therefore, the cancer-specific miRNA profiles are increasingly used in the clinical cancer diagnosis. Some circulating miRNAs are already evidenced as potential early diagnostic biomarkers in the cancers of breast [50], colorectum [51], pancreas [52], and liver [53].

\section{miRNA and cancer outcome}

Several miRNAs are reported to be correlated to clinical cancer outcomes. However, the miRNAs can be as onco-miR or anti-onco-miR depending on cancer types. Among onco-miRs, miR-21 is widely recognized as the onco-miR in any cancer types per se. Several clinical reports revealed that the upregulation of miR-21 expression in cancer tissue and blood was positively related with chemoresistance, poor progression-free survival, worse overall survival in breast [54], pancreas [55], rectal [56], squamous cancer [57], colorectal [58], lung [59], renal cancers [60] and lymphoma [61]. miR-125 was also reported as an onco-miR among the cancer patients with squamous cancer carcinoma [62], gastrointestinal stromal tumor [63], oesophagus cancers [64], whereas it was recognised as an anti-onco-miR among cervical [65], gallbladder [66] and colorectal cancers [67]. Similarly, miR-9 was documented as an onco-miR in breast cancer [68], glioma [69] and lymphoma [70], but as anti-onco$\mathrm{miR}$ in oral squamous carcinoma [71]. Also, miR-455-3p was shown to be as an onco-miR in glioma [72], but as anti-onco-miR in liver [73], breast [44] and lung cancer [46] and osteosarcoma [74]. Thus, each cancer type has its own onco-miRs and anti-miRs and each individual miRNA can be pro- and anti-cancer modulator in different cancers.

\section{miRNA as a therapeutic target}

miRNAs also can be the therapeutic targets of cancers. One of the pivotal advantages of miRNAs as therapeutic targets is the capability of multiple regulations in several pathways, which is favourable to the efficient regulation of cancer cell biology. For example, silencing oncogenic miR-21 with antisense oligonucleotides promotes cancer cell apoptosis and suppressed proliferation in vitro, and reduced tumor mass volume in vivo [75]. Moreover, a chemotherapy agent based on a miR-34a mimic (MRX34) has reached out to the phase I clinical trial [76]. miR-34a is known as one of tumor miRNA suppressors, downregulating over 30 major oncogenes including TP-53 [77] and Programmed death-ligand 1 (PD-L1) [78, 79]. Clinical histology analysis showed that the reduced miR-34a expression in the primary tumor tissue was related with higher TP-53 expression in glioma [80], chemoresistance in breast cancer [81], and worse mortality in colon [82], prostate [83] and ovarian cancer patients [84]. From numerous in vitro studies, miR-34a can regulate vital oncogenesis processes, e.g. cancer apoptosis, chemoresistance, proliferation, migration and invasion in the cell lines of brain [77, 78, 85], esophagus [86], stomach [87], lung [88], breast [89, 90], prostate [91, 92], ovary [93] and leukaemia [94, 95]. Several in vivo studies suggested that miR-34a derivative treatment supressed tumor growth [96, 97], metastasis [98] and improved survival $[99,100]$. The results of a phase I clinical trial of MRX34, miR-34a mimic confirmed the acceptable safety for 85 patients with hepatic primary/metastatic solid tumors and mild hepatic dysfunction [76]. Those patients received with several doses of MRX34 treatments $(50(n=4), 70(n=16), 93(n=16)$ and finally $\left.110 \mathrm{mg} \cdot \mathrm{m}^{-2}(n=9)\right)$ with dexamethasone in $3+3$ dose-escalation cohorts. The severe side effects were fever (grade 3,4\%), chills (14\%), fatigue (9\%), and back pain $(5 \%)$. Four participants resulted in death due to bloody diarrhea with worsening respiratory dysfunction, multiple organ failure by disease progression, substantial brain metastasis, and cytokine release syndrome after bronchial hemorrhage, respectively. Biopsy evidenced the direct delivery of miR-34a to tumor cell 
cytoplasm by MRX34 treatment, whereas miR-34a target oncogenes were significantly suppressed in peripheral leukocytes in MRX34 dose-dependent manner (compared to pre-dose level, the combined mRNA expressions of B-cell lymphoma 2 (BCL2), DnaJ homolog subfamily B member 1 (DNAJB1), Catenin Beta 1 (CTNNB1), Forkhead box protein P1 (FOXP1) and Histone deacetylase 1 (HDAC1), MRX34 dose $50(n=4)$, $p=0.0005,70 \quad(n=16), \quad p=0.0311,93 \quad(\mathrm{n}=16), \quad p=$ $0.0299,110 \mathrm{mg} \cdot \mathrm{m}^{-2}(n=9)$, not significant $\left.)\right)$. As for the clinical disease status, MRX treatment stabilised the disease in 16 patients (24\%) for 19 weeks as median (range, 11-55 weeks), but partial response confirmed in three patients (4\%) and progressive disease in 31 patients (47\%). Further study in terms of efficient dose and regimen is needed.

\section{miRNAs and their changes during perioperative period} It is widely known that many perioperative medications affected miRNA expressions [101] including and anticoagulants. Celecoxib, one of commonly used NSAIDs (non-steroidal anti-inflammatory drugs), has been reported to inhibit cancer cell proliferation, migration, and invasion in osteosarcoma cells via miR-34a [102], and the expressions of miR-126-5p, $-320 \mathrm{a}$ and $-146 \mathrm{a}-5 \mathrm{p}$ were correlated with the sensitivity to celecoxib [103]. Aspirin regulated miR-155/eNOS (endothelial nitric oxide synthase) pathway and suppressed endothelial cell dysfunction under the inflammation [104]. Also, aspirin suppressed the expression of miR-24, - 191 and - 197 in plasma [105].

Surgical stress, inflammation in mucosa, epithelial and immune alteration all can be modulated by miRNA changes after anaesthesia. miR-223 was considered as a key miRNA among the anti-inflammation mechanism, which regulated the intestine macrophage differentiation and function [106]. The miR-223 upregulation was reported in the condition of the intestinal inflammation [107]. In addition, the upregulation of miR-223 was documented in acute respiratory distress syndrome/acute lung injury (ARDS/ALI) patients [108]. The miR-223 shuttling by pulmonary neutrophils to alveolar epithelial cells may be a novel therapy against ARDS [109]. Thus, if cancer patient develops ARDS after surgery, mRNA, inflammation, and immune cell changes all interacted together make patient's conditions more complex.

Some miRNA changes can modulate the patient's immune cell phenotype/balance changes. It has been reported that regulatory $\mathrm{T}$ cell immune activities were regulated by miR-125a [110], and the inflammatory $\mathrm{T}$ cell immunity were controlled by miR-146a expression [111]. In the lung cancer, miR-301a dysfunction led CD8+ $\mathrm{T}$ cell infiltration into the tumour microenvironment with the anti-tumor immune activation [112]. Also
miR-582 regulated CD1B expression and dendritic cell function in the advanced lung adenocarcinoma [113], and miR-341 was reported to be related to leukocyte function [114] and immune escape [115].

Furthermore, some miRNAs have been found as potential biomarkers for perioperative organ injury including postoperative cognitive dysfunction (POCD), acute cardiac ischemia, deep venous thrombosis (DVT) and acute kidney injury (AKI) [116]. The mice model of POCD showed that miR-146a [117] or -181b-5p [118] inhibited the hippocampi inflammation and POCD development. The increased miR-122 expression in serum was found in the ischemic postconditioning [119], whereas the upregulation of miR339-5p and-483-3p, and the downregulation of miR-139-5p in blood were documented in acute cardiac ischemia [120]. Also, the miR-1, -133a and -499 expressions were correlated positively with pro-BNP (brain natriuretic peptide) and negatively with left ventricular ejection fraction [121]. miR-100 expression in plasma was related with the coronary plaque vulnerability [122]. It showed that the upregulation of miR-495 in plasma was related to a lower DVT possibility in a rat model [123]. In addition, miR-21 may be a biomarker of severe AKI after cardiac surgery $[124,125]$. In an in vitro model, miR-146 augmented AKI via interleukin-8/CXCL (chemokine (C-X$\mathrm{C}$ motif) ligand) signaling in the tubular cells [126].

\section{Anesthetics and miRNAs}

It is known that anesthetic itself can change gene expressions. Microarray analysis in various organs showed that inhalational anesthetics affect $1.5 \%$ gene expression of 10,000 genes [127]. Sevoflurane was reported to change the expression of the circadian genes [128] and the genes encoding drug metabolizing enzymes [129]. However, molecular biological research utilizing proteomics did not identify an association of anesthetics induced gene and protein expression changes [130]. Some miRNA profiling studies showed that both sevoflurane and propofol affect miRNA expressions in liver [131], lung [132], and brain [133], all of which has its specific pattern of expression after each anesthetic exposure [131, 132]. Out of 177 expressed miRNAs in mice liver, 46 miRNA expressions were changed after sevoflurane or propofol exposure [131]. Especially, there was significant difference in the expression of miR-1423p, miR-29a and miR-378 after sevoflurane and propofol exposure [131]. In mice lung, 20 miRNA expressions were significantly altered after sevoflurane exposure when compared to the controls and 16 miRNA expressions were changed after 4\% sevoflurane exposure with specific expression patterns [132]. Also, 14 miRNAs were significantly different after sevoflurane and propofol exposure in mice hippocampi [133]. Hence, different 
anesthetics that induce unique changes in miRNA expression patterns in organs may have specific effects. Therefore, post-transcriptional factors such as miRNAs that may control the regulation of gene expression are expected to play a crucial role in the biological effects of anesthetics.

Previous reports revealed that inhalational and intravenous anesthesia affect disease outcomes via miRNAs. Sevoflurane exerts hepato-protective effects by inducing miR-9-5p expression in ischaemia-reperfusion injury. miR-9-5p targets nuclear factor-kappa B (NF-кB) 3, coding for $\mathrm{p} 65$, which is a key protein in the NF- $\mathrm{kB}$ signaling pathway. Sevoflurane inhibits the NF- $\mathrm{kB}$ signaling pathway and protects the liver from ischaemiareperfusion injury by increasing miR-9-5p expression [134]. Sevoflurane also ameliorates systemic inflammation in acute lung injury model through miR-155 downregulation [135]. Propofol inhibits lipopolysaccharideinduced neuroinflammation partly by decreasing tumor necrosis factor- $\alpha$, interleukin- 6 , and nitric oxide by miR155 suppression [136]. Propofol may also have a therapeutic effect in suppressing sepsis-induced renal injury by activating miR-290-5p and the subsequent inhibition of $\mathrm{C}-\mathrm{C}$ motif chemokine ligand 2 and its downstream pathways [137].

\section{Anesthetics, miRNAs and immune function}

Several research revealed that both anesthesia and miRNA varied the immune response in vitro and in vivo. Natural killer (NK) cells are an early cellular defense in the immune system against cancer, which is regulated by miR-181. miR-181 promotes the differentiation of NK cells by targeting Nemo-like kinase and also suppresses the upstream of interferon translation during NK cell activation [138]. Inhalational anesthetics can suppress NK cell activity [139-141], recruitment of macrophages [142] and dendritic cells [143], and cause helper $\mathrm{T}$ (Th) polarization from an anti-tumor phenotype (Th1) to a cancer-promoting phenotype (Th2) [144]. In contrast, propofol can increase cytotoxic $\mathrm{T}$ lymphocyte (anti-tumor) activity [145], and also exhibits anti-inflammatory and antioxidative properties through inhibiting cyclooxygenase-2 and prostaglandin E2 [146]. Multiple receptors on immune cells can be also affected by anesthetics in a wide range of immune function [147]. Previous in vivo studies have shown that inhalational anesthetics reduce NK cytotoxic activity in peripheral blood [139], the number of peripheral leukocytes [142], and alveolar macrophages [148]. However, some clinical studies showed that the choice of sevoflurane or propofol did not show significant difference in circulating percentage of NK cell [149], cytotoxic T lymphocytes [149], regulatory $\mathrm{T}$ cells (Treg) [150], and
Th1/Th17 ratio in breast cancer surgery [150]. Although miRNAs can cause the differentiation of immune cells and indirectly modulate anti-cancer immunity, how anesthetics affect miRNAs and then indirectly change anti-cancer immune function remain unknown.

\section{Anesthetics, cancers and miRNAs}

Inhalational anesthetics increase the expression of cellular mediators that promote proliferation and migration of cancer cells [151-153]. Sevoflurane promotes the proliferation of glioma stem cells and may increase postsurgical recurrence by upregulation of hypoxia-inducible factor- $1 \alpha$ (HIF-1 $\alpha$ ) and vascular endothelial growth factor [154]. The increased HIF$1 \alpha$ correlates with cancer progression and could serve as a potential therapeutic target in cancer patients [155]. However, sevoflurane may also suppress malignant progression in some cancer cell types through a decreased release of matrix metalloproteinase-2 (MMP-2) and MMP-9, partly due to inactivation of the p38 mitogen-activated protein kinase signaling pathway in lung adenocarcinoma cells, resulting in anti-invasion and antimigration effects [156]. Propofol was reported to have anti-cancer effects in several tumor cells with increasing apoptosis and reducing cell proliferation [157-159]. Propofol also reduces the level of MMP by inhibiting NF- $\mathrm{kB}$ pathways, migration, and invasion in breast cancer [160].

Suppressing breast cancer cell proliferation by arresting the cell cycle at the G1 phase was documented via upregulated miR-203 by sevoflurane [161] (Fig. 2a). In colorectal cancer cell, sevoflurane inhibits cancer invasion and migration by downregulation of ERK (extracellular signal-regulated kinases) pathway and MMP-9 via miR-203 upregulation [162]. The inhibitory effects of sevoflurane on glioma cell migration and invasion are mediated by the upregulation of miR-637, which was due to the suppression of Akt (protein kinase B) expression and activity [163]. Isoflurane enhances the cancer malignancy with miR-21 upregulation with the increase of glycolysis product and the related enzymes through Akt phosphorylation [164].

During tumor development, MMPs digest various extracellular matrix components, including proteoglycans, collagen and fibronectin, and provide a favourable environment for primary tumorigenesis. MMPs induce tumor cell migration by removing sites of adhesion, exposing new sites for tumor growth, and releasing procancer factors from the extracellular matrix. Propofol inhibits cell proliferation and MMP-2 expression, and induces apoptosis by miR-218 upregulation in gastric cancer [165] and miR-451 upregulation in glioblastoma 

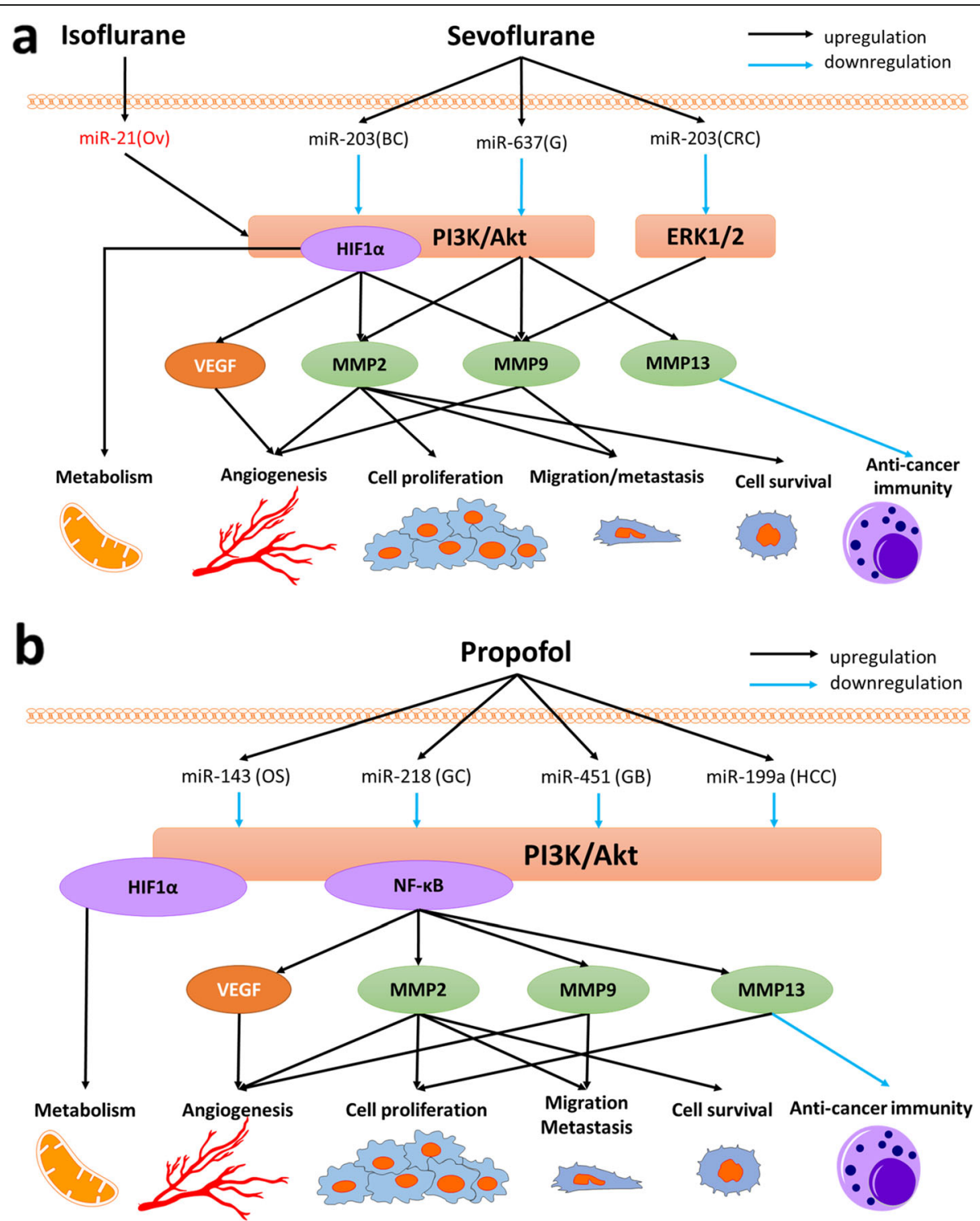

Fig. 2 Anesthetic affect pro- and anti-cancer miRNA expressions leading to cancer biology changes. a. Inhalational anesthetic reagents modulate miRNA expressions. Isoflurane exposure to ovarian cancer cells increases glycolysis via PI3K/Akt pathway and HIF-1a by miR-21 upregulation, one of oncogenes. Sevoflurane inhibits cancer cell proliferation via PI3K/Akt pathway with miR-203 upregulation in breast cancer cells. In CRC, sevoflurane reduces cancer invasion and migration via the suppression of ERK pathway and MMP-9 by miR-203 upregulation. For glioma cells, sevoflurane increases miR-637 expressions resulting in the decrease of cancer migration and invasion via Akt pathway inhibition. b. Propofol exposure alters anti-cancer miRNAs. Propofol upregulates miR-143 in osteosarcoma cells, decreasing cancer cell proliferation by MMP-13 inhibition via PI3K/Akt pathway. In gastric cancer cells, propofol exposure induces apoptosis via PI3K/Akt pathway and MMP-2 by miR-218 upregulation whereas propofol causes apoptosis by miR-451 in glioblastoma cells. For hepatocellular carcinoma, propofol decreases MMP-9 expression by PI3K Akt pathway suppression via miR-199a upregulation. Ov: ovarian cancer cell, BC: breast cancer cell, G: glioma, CRC: colorectal cancer, OS: osteosarcoma, GC: gastric cancer, GB: glioblastoma, HCC: hepatocellular carcinoma, PI3K/Akt: Phosphatidylinositol 3-kinase/protein kinase B, ERK1/ 2: extracellular signal-regulated kinases 1 and 2, HIF-1a: hypoxia-inducible factors 1a, NF-kB: nuclear factor-kB, VEGF: vascular endothelial growth factor, MMP: matrix metallopeptidases

cell line [166] (Fig. 2b). Propofol was also reported to decrease hepatocellular carcinoma invasiveness partly due to MMP-9 suppression by miR-199a upregulation [167] and inhibit osteosarcoma cell proliferation through affecting miR-143 expression, which regulates MMP-13 protein expression [159].
miRNAs as cell-to-cell communication factors induced by anesthetics

Cell-to-cell communication is critical for regulating biological functions (Fig. 3). The communication occurs directly by cell-to-cell contact, e.g., via cell surface ligand-receptor interactions and gap junctions, and also 


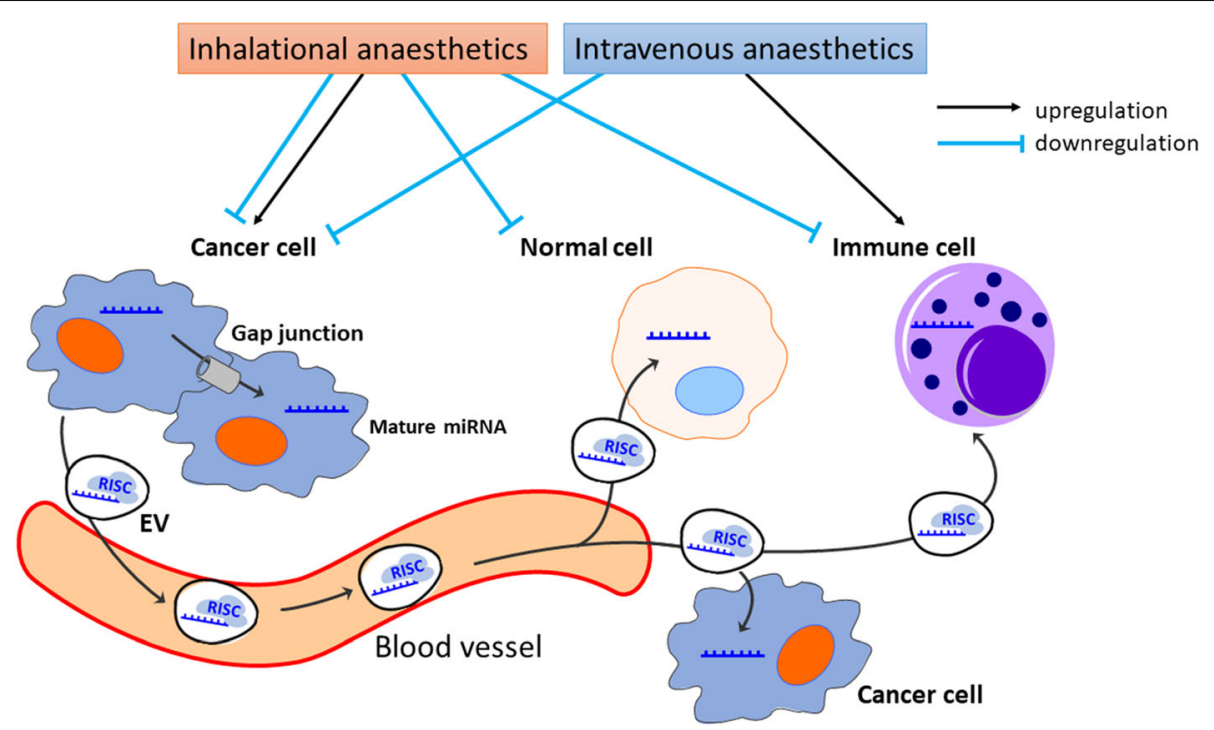

Fig. 3 The anesthetic effects on cancer cell biology, anti-cancer immunity, and cell-to-cell communication via miRNAs. Anesthetic exposure during cancer surgery can affect normal cells, anti-cancer immune cells and cancer cells directly or indirectly via miRNA expression changes. Mature miRNA induced by anesthesia inhibits its target protein expression in the affected cell and the adjacent cell with gap junction. Also, miRNA with RISC is released as EV from cells by exocytosis or in microvesicles, which enable miRNA to alter the target protein expressions in the distant cells including normal cells, anti-cancer immune cells and other cancer cells: 'cell-to-cell communication'. miRNA: micro RNA, RISC: RNAinduced silencing complex, EV: extracellular vesicle

indirectly through secretion of mediators such as cytokines and hormones [168]. Extracellular vesicles (EVs) are important indirect cell-to-cell communication carriers. Circulating EVs are found in body fluids such as saliva, blood, serum, and urine, and all are in enriched with mRNAs and miRNAs. Propofol may, at least in part, have anti-cancer effects via miRNA-mediated cellto-cell communication [169]. Propofol-regulated miRNAs inhibit cellular signaling pathways via their downstream effectors that are involved in cell proliferation, migration, and epithelial-mesenchymal transition of tumor cells. In this way, propofol can induce apoptosis of colorectal cancer cells. However, no clinical evidence indicates that miRNAs in circulating EVs can affect cancer recurrence and hence long-term outcomes and further studies are needed.

\section{Clinical relevance}

Both inhalational and intravenous anesthetics are widely used for cancer surgery. Inhalational anesthetics are increasingly associated with worse cancer outcomes compared to intravenous anesthetics used during cancer surgery. Some retrospective clinical data showed that propofol-based total intravenous anesthesia (TIVA) provides better outcomes in breast, colon, rectal, gastric, and oesophageal cancers [170-173]. Conversely, Kim et al. reported that recurrence and overall survival following TIVA for breast cancer surgery are not significantly different compared to surgery under inhalational anesthesia [174]. Inhalational anesthesia might be comparable to TIVA with regard to overall survival in patients with various cancers $[175,176]$. A large retrospective study indicated no significant relation to anesthetic type and recurrence free survival (hazard ratio (HR), 0.96; 95\% CI, 0.69-1.33, $p=0.782$ ) nor overall survival among breast cancer patients with propensity matching (any inhalational anesthetics vs propofol-based TIVA, $n=1766$ each, HR, 0.96; 95\% CI, 0.69-1.33, $p=$ $0.805)$ [176]. A study among high-grade glioma patients showed that sevoflurane did not change progression-free survival, but worsen the mortality (the risk of death after sevoflurane use during surgery, $\mathrm{HR}, 1.66$; $95 \% \mathrm{CI}, 1.08$ 2.57; $P=0.022$ ) and overall survival among patients with reduced performance status (median of overall survival, sevoflurane, $n=154$ vs propofol, $n=140,15$ months vs 11 months; $P=0.017$ ). Another study showed that propofol-based TIVA or any inhalational anesthetics had no effects on cancer recurrence nor mortality in nonsmall lung cell carcinoma patients with the matching performance status (any inhalational anesthetics vs propofol-based TIVA, $n=181$ each, cancer recurrence, HR 1.310; 95\% CI, 0.841-2.041; $p=0.233$, mortality, HR 0.902; 95\% CI, $0.643-1.265 ; p=0.551$ ) [175]. Furthermore, the consensus statement derived from the BJA Workshop on Cancer and Anesthesia stated that there is insufficient evidence to support any change in current clinical practice [177], and which anesthetic techniques are suitable for cancer surgeries remains unclear. In 
addition, at this moment, the clinical impact of miRNA alterations on cancer outcomes is still unclear. Therefore, the anesthetic mechanisms on cancer cell biology are still subjected to investigate further.

\section{Conclusion}

Inhalational and intravenous anesthetics have both proand anti-cancer effects through various pathways by adjustment of miRNAs. Their effects vary depending on the cancer cell type. Although our understanding of the potential influence of anesthetics on cancer cell biology has been greatly increased by laboratory investigations, a limited number of publications of the effects of anesthetics on cancer cells by miRNA expression changes have been published but the impact of those data on clinical outcomes remains largely unknown. Further studies are needed to integrate basic scientific findings and clinical data related to the effects of anesthetics on cancer cell progression, anti-cancer immunity, cell-tocell communication, and clinical outcomes via miRNA modulation. Prospective clinical trials are ongoing to investigate the effects of anesthetics on cancer recurrence and survival. Undoubtedly, bridging the gap between basic research findings and clinical data towards evidence-based treatment reminds a challenge, but even a small progress of that will have enormous potential in improving patient outcomes. To this end, the molecular effects including miRNAs of anesthetics on cancer cell "behavioral" changes are needed to investigate further and ultimately optimal anesthetic regimens can be implemented for cancer surgery.

\section{Abbreviations}

miRNAs: microRNA; XIAP: X-linked inhibitor of apoptosis; PD-L1: Programmed death-ligand 1; BCL2: B-cell lymphoma 2; DNAJB1: DnaJ homolog subfamily B member 1; CTNNB1: Catenin Beta 1; FOXP1: Forkhead box protein P1; HDAC1: Histone deacetylase 1; eNOS: Endothelial nitric oxide synthase; NSAI Ds: Non-steroidal anti-inflammatory drugs; ARDS/ALI: Acute respiratory distress syndrome/acute lung injury; POCD: Postoperative cognitive dysfunction; DVT: Deep venous thrombosis; AKI: Acute kidney injury; proBNP: Pro-brain natriuretic peptide; CXCL: Chemokine (C-X-C motif) ligand; NK: Natural killer; NF-kB: Nuclear factor-kappa B; HIF-1a: Hypoxia-inducible factor-1; MMP: Matrix metalloproteinase; ERK: Extracellular signal-regulated kinases; Akt: Protein kinase B; EV: Extracellular vesicle; TIVA: Total intravenous anesthesia
}

\section{Acknowledgements}

Not applicable.

\footnotetext{
Authors' contributions

[Masashi Ishikawa, MI1] performed the conception and design of the work, data acquisition, analysis, interpretation of data, writing the draft manuscrip and revising the manuscript. [Masae Iwasaki, MI2] contributed to the data analysis, interpretation of data, writing the draft manuscript and revising the manuscript. [Atsuhiro Sakamoto, AS] contributed to interpretation of data revising the manuscript and supervision. [Daqing Ma, DM] contributed to conception and design of the work, interpretation of data, revising the manuscript and supervision of all the process. All authors have read and approved the final manuscript.
}

\section{Funding}

M.Ishikawa is supported by the Japan Society for the Promotion of Science (Grant-in-Aid for Scientific Research (C), grant numbers JP18K08870) and ONO PHARMACEUTICAL CO., LTD. (ONOS20190517001); This area of research of D.M.'s group is supported by BOC Chair grant, Royal College of Anaesthetists, London, UK

\section{Availability of data and materials}

The datasets used and/or analysed during the current study available from the corresponding author on reasonable request.

\section{Declarations}

Ethics approval and consent to participate

Not applicable.

\section{Consent for publication}

Not applicable (review article).

\section{Competing interests}

Prof Daqing $\mathrm{Ma}$ is an editorial board member of BMC anesthesiology. Other authors declare that they have no competing interests.

Received: 20 November 2020 Accepted: 1 March 2021

Published online: 09 March 2021

\section{References}

1. Alkire BC, Raykar NP, Shrime MG, Weiser TG, Bickler SW, Rose JA, Nutt CT, Greenberg SLM, Kotagal M, Riesel JN, et al. Global access to surgical care: a modelling study. Lancet Glob Health. 2015;3(6):e316-23.

2. Mehlen P, Puisieux A. Metastasis: a question of life or death. Nat Rev Cancer 2006:6(6):449-58.

3. Nepogodiev D, Martin J, Biccard B, Makupe A, Bhangu A, et al. Global burden of postoperative death. Lancet. 2019;393(10170):401.

4. Sloan EK, Priceman SJ, Cox BF, Yu S, Pimentel MA, Tangkanangnukul V, Arevalo JM, Morizono K, Karanikolas BD, Wu L, et al. The sympathetic nervous system induces a metastatic switch in primary breast cancer. Cancer Res. 2010;70(18):7042-52

5. Thaker PH, Han LY, Kamat AA, Arevalo JM, Takahashi R, Lu C, Jennings NB, Armaiz-Pena G, Bankson JA, Ravoori M, et al. Chronic stress promotes tumor growth and angiogenesis in a mouse model of ovarian carcinoma. Nat Med. 2006;12(8):939-44.

6. Le CP, Nowell CJ, Kim-Fuchs C, Botteri E, Hiller JG, Ismail H, Pimentel MA, Chai MG, Karnezis T, Rotmensz N, et al. Chronic stress in mice remodels lymph vasculature to promote tumour cell dissemination. Nat Commun. 2016;7:10634.

7. Perry NJS, Buggy D, Ma D. Can anesthesia influence Cancer outcomes after surgery? JAMA Surg. 2019;154(4):279-80.

8. Huang $\mathrm{H}$, Benzonana LL, Zhao H, Watts HR, Perry NJ, Bevan C, Brown R, Ma D. Prostate cancer cell malignancy via modulation of HIF-1alpha pathway with isoflurane and propofol alone and in combination. Br J Cancer. 2014; 111(7):1338-49.

9. Wang C, Datoo T, Zhao H, Wu L, Date A, Jiang C, Sanders RD, Wang G, Bevan C, Ma D. Midazolam and Dexmedetomidine affect Neuroglioma and lung carcinoma cell biology in vitro and in vivo. Anesthesiology. 2018; 129(5):1000-14.

10. Wigmore TJ, Mohammed K, Jhanji S. Long-term survival for patients undergoing volatile versus IV anesthesia for Cancer surgery: a retrospective analysis. Anesthesiology. 2016;124(1):69-79.

11. Karp XAV. Developmental biology. Encountering microRNAs in cell fate signaling. Science. 2005;310:1288-9.

12. Chen CZ, LL, Lodish HF, Bartel DP. MicroRNAs modulate hematopoietic lineage differentiation. Science. 2004;303:83-6.

13. Stadler BM, Ruohola-Baker H. Small RNAs: keeping stem cells in line. Cell. 2008:132(4):563-6.

14. Yi R, Poy MN, Stoffel M, Fuchs E. A skin microRNA promotes differentiation by repressing 'stemness'. Nature. 2008;452(7184):225-9.

15. Cheng AM, Byrom MW, Shelton J, Ford LP. Antisense inhibition of human miRNAs and indications for an involvement of miRNA in cell growth and apoptosis. Nucleic Acids Res. 2005;33(4):1290-7. 
16. Forget $\mathrm{P}$, Aguirre JA, Bencic I, Borgeat A, Cama A, Condron C, Eintrei C, Eroles P, Gupta A, Hales TG, et al. How Anesthetic, Analgesic and Other Non-Surgical Techniques During Cancer Surgery Might Affect Postoperative Oncologic Outcomes: A Summary of Current State of Evidence. Cancers (Basel). 2019;11(5):592.

17. Wall T, Sherwin A, Ma D, Buggy DJ. Influence of perioperative anaesthetic and analgesic interventions on oncological outcomes: a narrative review. $\mathrm{Br}$ J Anaesth. 2019;123(2):135-50.

18. Brennecke J, Stark A, Russell RB, Cohen SM. Principles of microRNA-target recognition. PLoS Biol. 2005;3(3):e85.

19. Krek A, Grun D, Poy MN, Wolf R, Rosenberg L, Epstein EJ, MacMenamin P, da Piedade I, Gunsalus KC, Stoffel M, et al. Combinatorial microRNA target predictions. Nat Genet. 2005;37(5):495-500.

20. Calin GA, Croce CM. MicroRNA signatures in human cancers. Nat Rev Cancer. 2006:6(11):857-66.

21. Jansson MD, Lund AH. MicroRNA and cancer. Mol Oncol. 2012;6(6):590-610.

22. Liu Y, Zhou Y, Feng X, An P, Quan X, Wang H, Ye S, Yu C, He Y, Luo H. MicroRNA-126 functions as a tumor suppressor in colorectal cancer cells by targeting CXCR4 via the AKT and ERK1/2 signaling pathways. Int J Oncol. 2014;44(1):203-10.

23. Gu JJ, Gao GZ, Zhang SM. miR-218 inhibits the migration and invasion of glioma U87 cells through the Slit2-Robo1 pathway. Oncol Lett. 2015;9(4):1561-6.

24. Calin GA DC, Shimizu M, Bichi R, Zupo S, Noch E, Aldler H, Rattan S, Keating M RK, Rassenti L, Kipps T, Negrini M, Bullrich F, Croce CM.: Frequent deletions and down-regulation of micro- RNA genes miR15 and miR16 at $13 q 14$ in chronic lymphocytic leukemia. Proc Natl Acad Sci U S A 2002, 99: 15524-15529.

25. Santasusagna S, Moreno I, Navarro A, Munoz C, Martinez F, Hernandez R, Castellano JJ, Monzo M. miR-328 mediates a metabolic shift in colon cancer cells by targeting SLC2A1/GLUT1. Clin Transl Oncol. 2018;20(9):1161-7.

26. Xie Y, Tobin LA, Camps J, Wangsa D, Yang J, Rao M, Witasp E, Awad KS, Yoo $\mathrm{N}$, Ried T, et al. MicroRNA-24 regulates XIAP to reduce the apoptosis threshold in cancer cells. Oncogene. 2013;32(19):2442-51.

27. Gu H, Guo X, Zou L, Zhu H, Zhang J. Upregulation of microRNA-372 associates with tumor progression and prognosis in hepatocellular carcinoma. Mol Cell Biochem. 2013:375(1-2):23-30.

28. Guan C, Zhang L, Wang S, Long L, Zhou H, Qian S, Ma M, Bai F, Meng QH, Lyu J. Upregulation of MicroRNA-21 promotes tumorigenesis of prostate cancer cells by targeting KLF5. Cancer Biol Ther. 2019;20(8):1149-61.

29. Yao T, Lin Z. MiR-21 is involved in cervical squamous cell tumorigenesis and regulates CCL20. Biochim Biophys Acta. 2012;1822(2):248-60.

30. Su C, Cheng X, Li Y, Han Y, Song X, Yu D, Cao X, Liu Z. MiR-21 improves invasion and migration of drug-resistant lung adenocarcinoma cancer cell and transformation of EMT through targeting HBP1. Cancer Med. 2018;7(6): 2485-503.

31. Pratheeshkumar P, Son YO, Divya SP, Wang L, Zhang Z, Shi X. Oncogenic transformation of human lung bronchial epithelial cells induced by arsenic involves ROS-dependent activation of STAT3-miR-21-PDCD4 mechanism. Sci Rep. 2016;6:37227.

32. Medina PP, Nolde M, Slack FJ. OncomiR addiction in an in vivo model of microRNA-21-induced pre-B-cell lymphoma. Nature. 2010;467(7311):86-90,

33. $X u$ X, LV YG, Yan CY, Yi J, Ling R. Enforced expression of hsa-miR-125a-3p in breast cancer cells potentiates docetaxel sensitivity via modulation of BRCA1 signaling. Biochem Biophys Res Commun. 2016;479(4):893-900

34. Li X, Xu Y, Ding Y, Li C, Zhao H, Wang J, Meng S. Posttranscriptional upregulation of HER3 by HER2 mRNA induces trastuzumab resistance in breast cancer. Mol Cancer. 2018;17(1):113.

35. Ozcan O, Kara M, Yumrutas O, Bozgeyik E, Bozgeyik I, Celik OI. MTUS1 and its targeting miRNAs in colorectal carcinoma: significant associations. Tumour Biol. 2016;37(5):6637-45.

36. Gwak JM, Kim HJ, Kim EJ, Chung YR, Yun S, Seo AN, Lee HJ, Park SY. MicroRNA-9 is associated with epithelial-mesenchymal transition, breast cancer stem cell phenotype, and tumor progression in breast cancer. Breast Cancer Res Treat. 2014;147(1):39-49.

37. Roscigno G, Quintavalle C, Donnarumma E, Puoti I, Diaz-Lagares A, laboni M, Fiore D, Russo V, Todaro M, Romano G, et al. MiR-221 promotes stemness of breast cancer cells by targeting DNMT3b. Oncotarget. 2016;7(1):580-92.

38. Callegari E, Elamin BK, Giannone F, Milazzo M, Altavilla G, Fornari F, Giacomelli L, D'Abundo L, Ferracin M, Bassi C, et al. Liver tumorigenicity promoted by microRNA-221 in a mouse transgenic model. Hepatology. 2012;56(3):1025-33.
39. Tanaka R, Tomosugi M, Horinaka M, Sowa Y, Sakai T. Metformin causes G1phase arrest via Down-regulation of MiR-221 and enhances TRAIL sensitivity through DR5 up-regulation in pancreatic Cancer cells. PLoS One. 2015;10(5): e0125779.

40. White RA, Neiman JM, Reddi A, Han G, Birlea S, Mitra D, Dionne L, Fernandez P, Murao K, Bian L, et al. Epithelial stem cell mutations that promote squamous cell carcinoma metastasis. J Clin Invest. 2013;123(10): 4390-404.

41. Liu S, Kumar SM, Lu H, Liu A, Yang R, Pushparajan A, Guo W, Xu X. MicroRNA-9 up-regulates E-cadherin through inhibition of NF-kappaB1Snail1 pathway in melanoma. J Pathol. 2012;226(1):61-72.

42. Zheng L, Qi T, Yang D, Qi M, Li D, Xiang X, Huang K, Tong Q. microRNA-9 suppresses the proliferation, invasion and metastasis of gastric cancer cells through targeting cyclin D1 and Ets1. PLoS One. 2013;8(1):e55719.

43. Cho A. Dark matter's dark horse. Science. 2013:342(6158):552-3 555

44. Guo J, Liu C, Wang W, Liu Y, He H, Chen C, Xiang R, Luo Y. Identification of serum miR-1915-3p and miR-455-3p as biomarkers for breast cancer. PLoS One. 2018;13(7):e0200716.

45. Li Z, Meng Q, Pan A, Wu X, Cui J, Wang Y, Li L. MicroRNA-455-3p promotes invasion and migration in triple negative breast cancer by targeting tumor suppressor El24. Oncotarget. 2017;8(12):19455-66.

46. Gao X, Zhao H, Diao C, Wang X, Xie Y, Liu Y, Han J, Zhang M. miR-455-3p serves as prognostic factor and regulates the proliferation and migration of non-small cell lung cancer through targeting HOXB5. Biochem Biophys Res Commun. 2018:495(1):1074-80.

47. Zhao Y, Yan M, Yun Y, Zhang J, Zhang R, Li Y, Wu X, Liu Q, Miao W, Jiang H. MicroRNA-455-3p functions as a tumor suppressor by targeting elF4E in prostate cancer. Oncol Rep. 2017;37(4):2449-58.

48. Ni X, Ding Y, Yuan H, Shao J, Yan Y, Guo R, Luan W, Xu M. Long non-coding RNA ZEB1-AS1 promotes colon adenocarcinoma malignant progression via miR-455-3p/PAK2 axis. Cell Prolif. 2020;53(1):e12723.

49. Zheng J, Lin Z, Zhang L, Chen H. MicroRNA-455-3p inhibits tumor cell proliferation and induces apoptosis in HCT116 human Colon Cancer cells. Med Sci Monit. 2016:22:4431-7.

50. Antolin S, Calvo L, Blanco-Calvo M, Santiago MP, Lorenzo-Patino MJ, HazConde M, Santamarina I, Figueroa A, Anton-Aparicio LM, Valladares-Ayerbes M. Circulating miR-200c and miR-141 and outcomes in patients with breast cancer. BMC Cancer. 2015;15:297.

51. Zanutto S, Pizzamiglio S, Ghilotti M, Bertan C, Ravagnani F, Perrone F, Leo E, Pilotti S, Verderio P, Gariboldi M, et al. Circulating miR-378 in plasma: a reliable, haemolysis-independent biomarker for colorectal cancer. $\mathrm{Br}$ J Cancer. 2014;110(4):1001-7.

52. Kawaguchi T, Komatsu S, Ichikawa D, Morimura R, Tsujiura M, Konishi H, Takeshita H, Nagata H, Arita T, Hirajima S, et al. Clinical impact of circulating miR-221 in plasma of patients with pancreatic cancer. Br J Cancer. 2013; 108(2):361-9.

53. Mirzaei HR, Sahebkar A, Mohammadi M, Yari R, Salehi H, Jafari MH, Namdar A, Khabazian E, Jaafari MR, Mirzaei H. Circulating microRNAs in hepatocellular carcinoma: potential diagnostic and prognostic biomarkers. Curr Pharm Des. 2016;22(34):5257-69.

54. Anwar SL, Sari DNI, Kartika Al, Fitria MS, Tanjung DS, Rakhmina D, Wardana T, Astuti I, Haryana SM, Aryandono T. Upregulation of circulating MiR-21 expression as a potential biomarker for therapeutic monitoring and clinical outcome in breast Cancer. Asian Pac J Cancer Prev. 2019:20(4):1223-8.

55. Khan K, Cunningham D, Peckitt C, Barton S, Tait D, Hawkins M, Watkins D, Starling N, Rao S, Begum R, et al. miR-21 expression and clinical outcome in locally advanced pancreatic cancer: exploratory analysis of the pancreatic cancer Erbitux, radiotherapy and UFT (PERU) trial. Oncotarget. 2016;7(11): 12672-81

56. Campayo M, Navarro A, Benitez JC, Santasusagna S, Ferrer C, Monzo M, Cirera L. miR-21, miR-99b and miR-375 combination as predictive response signature for preoperative chemoradiotherapy in rectal cancer. PLoS One. 2018;13(11):e0206542.

57. Re M, Magliulo G, Gioacchini FM, Bajraktari A, Bertini A, Ceka A, Rubini C, Ferrante L, Procopio AD, Olivieri F. Expression levels and clinical significance of miR-21-5p, miR-let-7a, and miR-34c-5p in laryngeal squamous cell carcinoma. Biomed Res Int. 2017;2017:3921258.

58. Mima K, Nishihara R, Yang J, Dou R, Masugi Y, Shi Y, da Silva A, Cao Y, Song M, Nowak J, et al. MicroRNA MIR21 (miR-21) and PTGS2 expression in colorectal Cancer and patient survival. Clin Cancer Res. 2016;22(15):3841-8. 
59. Yang M, Shen H, Qiu C, Ni Y, Wang L, Dong W, Liao Y, Du J. High expression of miR-21 and miR-155 predicts recurrence and unfavourable survival in non-small cell lung cancer. Eur J Cancer. 2013;49(3):604-15.

60. Vergho D, Kneitz S, Rosenwald A, Scherer C, Spahn M, Burger M, Riedmiller $\mathrm{H}$, Kneitz B. Combination of expression levels of miR-21 and miR-126 is associated with cancer-specific survival in clear-cell renal cell carcinoma. BMC Cancer. 2014;14:25.

61. Ting CY, Liew SM, Price A, Gan GG, Bee-Lan Ong D, Tan SY, Bee PC. Clinical significance of aberrant microRNAs expression in predicting disease relapse/ refractoriness to treatment in diffuse large B-cell lymphoma: a meta-analysis. Crit Rev Oncol Hematol. 2019;144:102818.

62. Vo DT, Karanam NK, Ding L, Saha D, Yordy JS, Giri U, Heymach JV, Story MD. miR-125a-5p functions as tumor suppressor microRNA and is a marker of Locoregional recurrence and poor prognosis in head and neck Cancer. Neoplasia. 2019;21(9):849-62.

63. Akcakaya P, Caramuta S, Ahlen J, Ghaderi M, Berglund E, Ostman A, Branstrom $R$, Larsson C, Lui WO. microRNA expression signatures of gastrointestinal stromal tumours: associations with imatinib resistance and patient outcome. Br J Cancer. 2014;111(11):2091-102.

64. Wu C, Li M, Hu C, Duan H. Prognostic role of microRNA polymorphisms in patients with advanced esophageal squamous cell carcinoma receiving platinum-based chemotherapy. Cancer Chemother Pharmacol. 2014;73(2): 335-41.

65. Fan Z, Cui H, Xu X, Lin Z, Zhang X, Kang L, Han B, Meng J, Yan Z, Yan X, et al. MiR-125a suppresses tumor growth, invasion and metastasis in cervical cancer by targeting STAT3. Oncotarget. 2015:6(28):25266-80.

66. Yang L, Huang S, Ma H, Wu X, Feng F. MicroRNA-125b predicts clinical outcome and suppressed tumor proliferation and migration in human gallbladder cancer. Tumour Biol. 2017;39(3):1010428317692249.

67. Hou $\mathrm{P}$, Li H, Yong H, Chen F, Chu S, Zheng J, Bai J. PinX1 represses renal cancer angiogenesis via the mir-125a-3p/NEGF signaling pathway. Angiogenesis. 2019;22(4):507-19.

68. Cheng CW, Yu JC, Hsieh YH, Liao WL, Shieh JC, Yao CC, Lee HJ, Chen PM, Wu PE, Shen CY. Increased cellular levels of MicroRNA-9 and MicroRNA-221 correlate with Cancer Stemness and predict poor outcome in human breast Cancer. Cell Physiol Biochem. 2018;48(5):2205-18.

69. Wu Z, Wang L, Li G, Liu H, Fan F, Li Z, Li Y, Gao G. Increased expression of microRNA-9 predicts an unfavorable prognosis in human glioma. Mol Cell Biochem. 2013;384(1-2):263-8.

70. Chuang MK, Chiu YC, Chou WC, Hou HA, Chuang EY, Tien HF. A 3microRNA scoring system for prognostication in de novo acute myeloid leukemia patients. Leukemia. 2015:29(5):1051-9.

71. Sun L, Liu L, Fu H, Wang Q, Shi Y. Association of Decreased Expression of serum miR-9 with poor prognosis of Oral squamous cell carcinoma patients. Med Sci Monit. 2016;22:289-94

72. Chen C, Gong X, Yang X, Shang X, Du Q, Liao Q, Xie R, Chen Y, Xu J. The roles of estrogen and estrogen receptors in gastrointestinal disease. Oncol Lett. 2019;18(6):5673-80.

73. Lin $Y H$, Wu MH, Huang $Y H$, Yeh $C T$, Cheng ML, Chi HC, Tsai CY, Chung $\mathbb{H}$, Chen CY, Lin KH. Taurine up-regulated gene 1 functions as a master regulator to coordinate glycolysis and metastasis in hepatocellular carcinoma. Hepatology. 2018;67(1):188-203.

74. Yi X, Wang $Y, X u$ S. MiR-455-3p downregulation facilitates cell proliferation and invasion and predicts poor prognosis of osteosarcoma. J Orthop Surg Res. 2020;15(1):454.

75. Si ML, Zhu S, Wu H, Lu Z, Wu F, Mo YY. miR-21-mediated tumor growth Oncogene. 2007;26(19):2799-803.

76. Hong DS, Kang YK, Borad M, Sachdev J, Ejadi S, Lim HY, Brenner AJ, Park K, Lee JL, Kim TY, et al. Phase 1 study of MRX34, a liposomal miR-34a mimic, in patients with advanced solid tumours. Br J Cancer. 2020;122(11):1630-37.

77. Fan YN, Meley D, Pizer B, See V. Mir-34a mimics are potential therapeutic agents for p53-mutated and chemo-resistant brain tumour cells. PLoS One. 2014;9(9):e108514.

78. Wang Y, Wang L. miR-34a attenuates glioma cells progression and chemoresistance via targeting PD-L1. Biotechnol Lett. 2017;39(10):1485-92.

79. Cortez MA, Ivan C, Valdecanas D, Wang X, Peltier HJ, Ye Y, Araujo L, Carbone DP, Shilo K, Giri DK, et al. PDL1 Regulation by p53 via miR-34. J Natl Cancer Inst. 2015;108(1):djv303.

80. Jesionek-Kupnicka D, Braun M, Trabska-Kluch B, Czech J, Szybka M, Szymanska B, Kulczycka-Wojdala D, Bienkowski M, Kordek R, Zawlik I. MiR-21, miR-34a, miR-125b, miR-181d and miR-648 levels inversely correlate with
MGMT and TP53 expression in primary glioblastoma patients. Arch Med Sci. 2019:15(2):504-12.

81. Li ZH, Weng X, Xiong QY, Tu JH, Xiao A, Qiu W, Gong Y, Hu EW, Huang S, Cao YL. miR-34a expression in human breast cancer is associated with drug resistance. Oncotarget. 2017:8(63):106270-82.

82. Hiyoshi Y, Schetter AJ, Okayama H, Inamura K, Anami K, Nguyen GH, Horikawa I, Hawkes JE, Bowman ED, Leung SY, et al. Increased microRNA$34 \mathrm{~b}$ and $-34 \mathrm{c}$ predominantly expressed in stromal tissues is associated with poor prognosis in human colon cancer. PLoS One. 2015;10(4):e0124899.

83. Hagman Z, Larne O, Edsjo A, Bjartell A, Ehrnstrom RA, Ulmert D, Lilja H, Ceder Y. miR-34c is downregulated in prostate cancer and exerts tumor suppressive functions. Int J Cancer. 2010;127(12):2768-76.

84. Lee CH, Subramanian S, Beck AH, Espinosa I, Senz J, Zhu SX, Huntsman D, van de Rijn M, Gilks CB. MicroRNA profiling of BRCA1/2 mutation-carrying and non-mutation-carrying high-grade serous carcinomas of ovary. PLoS One. 2009;4(10):e7314.

85. Li Z, Chen H. miR-34a inhibits proliferation, migration and invasion of paediatric neuroblastoma cells via targeting HNF4alpha. Artif Cells Nanomed Biotechnol. 2019;47(1):3072-8.

86. Wang X, Zhao Y, Lu Q, Fei X, Lu C, Li C, Chen H. MiR-34a-5p inhibits proliferation, migration, invasion and epithelial-mesenchymal transition in esophageal squamous cell carcinoma by targeting LEF1 and inactivation of the hippo-YAP1/TAZ signaling pathway. J Cancer. 2020;11(10):3072-81.

87. Cao W, Fan R, Wang L, Cheng S, Li H, Jiang J, Geng M, Jin Y, Wu Y. Expression and regulatory function of miRNA-34a in targeting survivin in gastric cancer cells. Tumour Biol. 2013;34(2):963-71.

88. Bandi N, Vassella E. miR-34a and miR-15a/16 are co-regulated in non-small cell lung cancer and control cell cycle progression in a synergistic and Rbdependent manner. Mol Cancer. 2011;10:55.

89. Si W, Li Y, Shao H, Hu R, Wang W, Zhang K, Yang Q. MiR-34a inhibits breast Cancer proliferation and progression by targeting Wnt1 in Wnt/beta-catenin signaling pathway. Am J Med Sci. 2016;352(2):191-9.

90. Imani S, Wei C, Cheng J, Khan MA, Fu S, Yang L, Tania M, Zhang X, Xiao X, Zhang $X$, et al. MicroRNA-34a targets epithelial to mesenchymal transitioninducing transcription factors (EMT-TFs) and inhibits breast cancer cell migration and invasion. Oncotarget. 2017;8(13):21362-79.

91. Liao H, Xiao Y, Hu Y, Xiao Y, Yin Z, Liu L, Kang X, Chen Y. Methylationinduced silencing of miR-34a enhances chemoresistance by directly upregulating ATG4B-induced autophagy through AMPK/mTOR pathway in prostate cancer. Oncol Rep. 2016;35(1):64-72.

92. Liu X, Luo X, Wu Y, Xia D, Chen W, Fang Z, Deng J, Hao Y, Yang X, Zhang T, et al. MicroRNA-34a attenuates paclitaxel resistance in prostate Cancer cells via direct suppression of JAG1/Notch1 Axis. Cell Physiol Biochem. 2018; 50(1):261-76.

93. Zuo Y, Zheng W, Liu J, Tang Q, Wang SS, Yang XS. MiR-34a-5p/PD-L1 axis regulates cisplatin chemoresistance of ovarian cancer cells. Neoplasma. 2020;67(1):93-101.

94. Xiao X, Gu Y, Wang G, Chen S. c-Myc, RMRP, and miR-34a-5p form a positive-feedback loop to regulate cell proliferation and apoptosis in multiple myeloma. Int J Biol Macromol. 2019;122:526-37.

95. Sun JR, Zhang X, Zhang Y. MiR-214 prevents the progression of diffuse large B-cell lymphoma by targeting PD-L1. Cell Mol Biol Lett. 2019;24:68.

96. Cortez MA, Valdecanas D, Niknam S, Peltier HJ, Diao L, Giri U, Komaki R, Calin GA, Gomez DR, Chang JY, et al. In vivo delivery of miR-34a sensitizes lung tumors to radiation through RAD51 regulation. Mol Ther Nucleic Acids. 2015;4:e270.

97. Xie Y, Murray-Stewart T, Wang Y, Yu F, Li J, Marton LJ, Casero RA Jr, Oupicky D. Self-immolative nanoparticles for simultaneous delivery of microRNA and targeting of polyamine metabolism in combination cancer therapy. J Control Release. 2017;246:110-9.

98. Di Martino MT, Campani V, Misso G, Gallo Cantafio ME, Gulla A, Foresta U, Guzzi PH, Castellano M, Grimaldi A, Gigantino V, et al. In vivo activity of miR34a mimics delivered by stable nucleic acid lipid particles (SNALPS) against multiple myeloma. PLoS One. 2014;9(2):e90005.

99. Daige CL, Wiggins JF, Priddy L, Nelligan-Davis T, Zhao J, Brown D. Systemic delivery of a miR34a mimic as a potential therapeutic for liver cancer. Mol Cancer Ther. 2014;13(10):2352-60.

100. Craig VJ, Tzankov A, Flori M, Schmid CA, Bader AG, Muller A. Systemic microRNA-34a delivery induces apoptosis and abrogates growth of diffuse large B-cell lymphoma in vivo. Leukemia. 2012;26(11):2421-4.

101. Neudecker V, Brodsky KS, Kreth S, Ginde AA, Eltzschig HK. Emerging roles for MicroRNAs in perioperative medicine. Anesthesiology. 2016;124(2):489-506. 
102. Chen X, Peng D, Shen Y, Liu B, Zhou H, Tao H, Huang J. The potential combinational effect of miR-34a with celecoxib in osteosarcoma. AntiCancer Drugs. 2017;28(8):888-97.

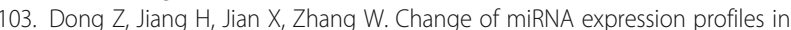
patients with knee osteoarthritis before and after celecoxib treatment. J Clin Lab Anal. 2019;33(1):e22648.

104. Kim J, Lee KS, Kim JH, Lee DK, Park M, Choi S, Park W, Kim S, Choi YK, Hwang JY, et al. Aspirin prevents TNF-alpha-induced endothelial cell dysfunction by regulating the NF-kappaB-dependent miR-155/eNOS pathway: role of a miR-155/eNOS axis in preeclampsia. Free Radic Biol Med. 2017;104:185-98.

105. Parker WAE, Schulte C, Barwari T, Phoenix F, Pearson SM, Mayr M, Grant PJ, Storey RF, Ajjan RA. Aspirin, clopidogrel and prasugrel monotherapy in patients with type 2 diabetes mellitus: a double-blind randomised controlled trial of the effects on thrombotic markers and microRNA levels. Cardiovasc Diabetol. 2020;19(1):3.

106. Zhou H, Xiao J, Wu N, Liu C, Xu J, Liu F, Wu L. MicroRNA-223 regulates the differentiation and function of intestinal dendritic cells and macrophages by targeting C/EBPbeta. Cell Rep. 2015;13(6):1149-60.

107. Neudecker V, Haneklaus M, Jensen O, Khailova L, Masterson JC, Tye H, Biette K, Jedlicka P, Brodsky KS, Gerich ME, et al. Myeloid-derived miR-223 regulates intestinal inflammation via repression of the NLRP3 inflammasome. J Exp Med. 2017;214(6):1737-52.

108. Feng Z, Qi S, Zhang Y, Qi Z, Yan L, Zhou J, He F, Li Q, Yang Y, Chen Q, et al. Ly6G+ neutrophil-derived miR-223 inhibits the NLRP3 inflammasome in mitochondrial DAMP-induced acute lung injury. Cell Death Dis. 2017;8(11):e3170.

109. Neudecker V, Brodsky KS, Clambey ET, Schmidt EP, Packard TA, Davenport B, Standiford TJ, Weng T, Fletcher AA, Barthel L, et al. Neutrophil transfer of miR-223 to lung epithelial cells dampens acute lung injury in mice. Sci Transl Med. 2017;9(408):eaah5360.

110. Pan W, Zhu S, Dai D, Liu Z, Li D, Li B, Gagliani N, Zheng Y, Tang Y, Weirauch MT, et al. MiR-125a targets effector programs to stabilize Treg-mediated immune homeostasis. Nat Commun. 2015;6:7096.

111. Emming S, Bianchi N, Polletti S, Balestrieri C, Leoni C, Montagner S, Chirichella M, Delaleu N, Natoli G, Monticelli S. A molecular network regulating the proinflammatory phenotype of human memory $\mathrm{T}$ lymphocytes. Nat Immunol. 2020;21(4):388-99.

112. Li X, Zhong M, Wang J, Wang L, Lin Z, Cao Z, Huang Z, Zhang F, Li Y, Liu M, et al. miR-301a promotes lung tumorigenesis by suppressing Runx3. Mol Cancer. 2019;18(1):99.

113. Guo J, Jin H, Xi Y, Guo J, Jin Y, Jiang D. The miR-582/CD1B Axis is involved in regulation of dendritic cells and is associated with clinical outcomes in advanced lung adenocarcinoma. Biomed Res Int. 2020;2020:4360930.

114. Hart M, Walch-Ruckheim B, Krammes L, Kehl T, Rheinheimer S, Tanzer T, Glombitza B, Sester M, Lenhof HP, Keller A, et al. miR-34a as hub of T cell regulation networks. J Immunother Cancer. 2019;7(1):187.

115. Zhou X, Mao Y, Zhu J, Meng F, Chen Q, Tao L, Li R, Fu F, Liu C, Hu Y, et al. TGF-beta1 promotes colorectal cancer immune escape by elevating $\mathrm{B} 7-\mathrm{H} 3$ and B7-H4 via the miR-155/miR-143 axis. Oncotarget. 2016;7(41):67196-211.

116. Kreth S, Hubner M, Hinske LC. MicroRNAs as clinical biomarkers and therapeutic tools in perioperative medicine. Anesth Analg. 2018;126(2):670-81.

117. Chen L, Dong R, Lu Y, Zhou Y, Li K, Zhang Z, Peng M. MicroRNA-146a protects against cognitive decline induced by surgical trauma by suppressing hippocampal neuroinflammation in mice. Brain Behav Immun. 2019:78:188-201.

118. Lu Y, Xu X, Dong R, Sun L, Chen L, Zhang Z, Peng M. MicroRNA-181b-5p attenuates early postoperative cognitive dysfunction by suppressing hippocampal neuroinflammation in mice. Cytokine. 2019;120:41-53.

119. Cui J, Deng J, Ding X, Zhang L, Zhang R, Wu W, Hao X, Liang H. Blood transfusion does not affect survival of gastric cancer patients. J Surg Res. 2016;200(1):98-104.

120. Saddic LA, Chang TW, Sigurdsson MI, Heydarpour M, Raby BA, Shernan SK, Aranki SF, Body SC, Muehlschlegel JD. Integrated microRNA and mRNA responses to acute human left ventricular ischemia. Physiol Genomics. 2015; 47(10):455-62

121. Hromadka M, Cerna V, Pesta M, Kucerova A, Jarkovsky J, Rajdl D, Rokyta R, Motovska Z. Prognostic value of MicroRNAs in patients after myocardial infarction: a substudy of PRAGUE-18. Dis Markers. 2019;2019:2925019.

122. Soeki T, Yamaguchi K, Niki T, Uematsu E, Bando S, Matsuura T, Ise T, Kusunose K, Hotchi J, Tobiume T, et al. Plasma microRNA-100 is associated with coronary plaque vulnerability. Circ J. 2015;79(2):413-8.
123. Li NX, Sun JW, Yu LM. Evaluation of the circulating MicroRNA-495 and Stat3 as prognostic and predictive biomarkers for lower extremity deep venous thrombosis. J Cell Biochem. 2018;119(7):5262-73.

124. Du J, Cao X, Zou L, Chen Y, Guo J, Chen Z, Hu S, Zheng Z. MicroRNA-21 and risk of severe acute kidney injury and poor outcomes after adult cardiac surgery. PLoS One. 2013;8(5):e63390.

125. Gaede L, Liebetrau C, Blumenstein J, Troidl C, Dorr O, Kim WK, Gottfried K, Voss S, Berkowitsch A, Walther T, et al. Plasma microRNA-21 for the early prediction of acute kidney injury in patients undergoing major cardiac surgery. Nephrol Dial Transplant. 2016;31(5):760-6.

126. Amrouche L, Desbuissons G, Rabant M, Sauvaget V, Nguyen C, Benon A Barre P, Rabate C, Lebreton X, Gallazzini M, et al. MicroRNA-146a in human and experimental ischemic AKI: CXCL8-dependent mechanism of action. J Am Soc Nephrol. 2017;28(2):479-93.

127. Sakamoto A, Imai J, Nishikawa A, Honma R, Ito E, Yanagisawa Y, Kawamura M, Ogawa R, Watanabe S. Influence of inhalation anesthesia assessed by comprehensive gene expression profiling. Gene. 2005;356:39-48.

128. Kobayashi K, Takemori K, Sakamoto A. Circadian gene expression is suppressed during sevoflurane anesthesia and the suppression persists after awakening. Brain Res. 2007;1185:1-7.

129. Nakazato KYY, Takemori K, Kobayashi K, Sakamoto A. Expressions of genes encoding drug-metabolizing enzymes are altered after sevoflurane, isoflurane, propofol or dexmedetomidine anesthesia. Biomed Res. 2009;30:17-24.

130. Tsuboko YSA. Propofol anaesthesia alters the cerebral proteome differently from sevoflurane anaesthesia. Biomed Res. 2011;32:55-65.

131. Ishikawa MTS, Arai M, Genda Y, Sakamoto A. Differences in microRNA changes of healthy rat liver between sevoflurane and propofol anesthesia. Anesthesiology. 2012;117:1245-52.

132. Tanaka SIM, Arai M, Genda Y, Sakamoto A. Changes in microRNA expression in rat lungs caused by sevoflurane anesthesia: a TaqMan ${ }^{\circledR}$ low-density array study. Biomed Res. 2012;33:255-63.

133. Goto G, Hori Y, Ishikawa M, Tanaka S, Sakamoto A. Changes in the gene expression levels of microRNAs in the rat hippocampus by sevoflurane and propofol anesthesia. Mol Med Rep. 2014;9(5):1715-22.

134. Liao X, Zhou S, Zong J, Wang Z. Sevoflurane exerts protective effects on liver ischemia/reperfusion injury by regulating NFKB3 expression via miR-95p. Exp Ther Med. 2019;17(4):2632-40.

135. Otsuki T, Ishikawa M, Hori Y, Goto G, Sakamoto A. Volatile anesthetic sevoflurane ameliorates endotoxin-induced acute lung injury via microRNA modulation in rats. Biomed Rep. 2015;3(3):408-12.

136. Lu YJM, Ouyang YB, Han RQ. Changes in rat brain MicroRNA expression profiles following Sevoflurane and Propofol anesthesia. Chin Med J. 2015; 128:1510-5.

137. Zheng G, Qu H, Li F, Ma W, Yang H. Propofol attenuates sepsis-induced acute kidney injury by regulating miR-290-5p/CCL-2 signaling pathway. Braz J Med Biol Res. 2018;51(11):e7655.

138. Cichocki F, Felices M, McCullar V, Presnell SR, Al-Attar A, Lutz CT, Miller JS. Cutting edge: microRNA-181 promotes human NK cell development by regulating notch signaling. J Immunol. 2011;187(12):6171-5.

139. Miyata T, Kodama T, Honma R, Nezu Y, Harada Y, Yogo T, Hara Y, Tagawa M Influence of general anesthesia with isoflurane following propofol-induction on natural killer cell cytotoxic activities of peripheral blood lymphocytes in dogs. J Vet Med Sci. 2013;75(7):917-21.

140. Tazawa K, Koutsogiannaki S, Chamberlain M, Yuki K. The effect of different anesthetics on tumor cytotoxicity by natural killer cells. Toxicol Lett. 2017;266:23-31.

141. Buckley A, McQuaid S, Johnson P, Buggy DJ. Effect of anaesthetic technique on the natural killer cell anti-tumour activity of serum from women undergoing breast cancer surgery: a pilot study. Br J Anaesth. 2014; 113(Suppl 1):i56-62

142. Elena GAN, Ferrero P, Bay ML, Valenti J, Colucci D, Puig NR. Effects of repetitive sevoflurane anaesthesia on immune response, select biochemical parameters and organ histology in mice. Lab Anim. 2003;37:193-203.

143. Inada T, Kubo K, Ueshima H, Shingu K. Intravenous anesthetic propofol suppresses prostaglandin E2 production in murine dendritic cells. J Immunotoxicol. 2011:8(4):359-66.

144. Inada T, Yamanouchi Y, Jomura S, Sakamoto S, Takahashi M, Kambara T, Shingu K. Effect of propofol and isoflurane anaesthesia on the immune response to surgery. Anaesthesia. 2004:59(10):954-9.

145. Kushida A, Inada T, Shingu K. Enhancement of antitumor immunity after propofol treatment in mice. Immunopharmacol Immunotoxicol. 2007;29(34):477-86. 
146. Kim JD, Ahn BM, Joo BS, Kwon JY, Chung HJ, Yu SB. Effect of propofol on prostaglandin E2 production and prostaglandin synthase-2 and cyclooxygenase-2 expressions in amniotic membrane cells. J Anesth. 2014 28(6):911-8.

147. Yuki K, Eckenhoff RG. Mechanisms of the immunological effects of volatile anesthetics: a review. Anesth Analg. 2016;123(2):326-35.

148. Kalimeris K, Christodoulaki K, Karakitsos P, Batistatou A, Lekka M, Bai M, Kitsiouli E, Nakos G, Kostopanagiotou G. Influence of propofol and volatile anaesthetics on the inflammatory response in the ventilated lung. Acta Anaesthesiol Scand. 2011;55(6):740-8

149. Lim JA, Oh CS, Yoon TG, Lee JY, Lee SH, Yoo YB, Yang JH, Kim SH. The effect of propofol and sevoflurane on cancer cell, natural killer cell, and cytotoxic T lymphocyte function in patients undergoing breast cancer surgery: an in vitro analysis. BMC Cancer. 2018;18(1):159.

150. Oh CS, Lee J, Yoon TG, Seo EH, Park HJ, Piao L, Lee SH, Kim SH. Effect of equipotent doses of Propofol versus Sevoflurane anesthesia on regulatory $T$ cells after breast Cancer surgery. Anesthesiology. 2018;129(5):921-31.

151. Iwasaki MZH, Jaffer T, Unwith S, Benzonana L, Lian Q, Sakamoto A, Ma D. Volatile anaesthetics enhance the metastasis related cellular signalling including CXCR2 of ovarian cancer cells. Oncotarget. Oncotarget. 2016;7: 26042-56.

152. Benzonana LLPN, Watts HR, Yang B, Perry IA, Coombes C, Takata M, Ma D. Isoflurane, a commonly used volatile anesthetic, enhances renal cancer growth and malignant potential via the hypoxia-inducible factor cellular signaling pathway in vitro. Anesthesiology. 2013;119:593-605.

153. Luo X, Zhao H, Hennah L, Ning J, Liu J, Tu H, Ma D. Impact of isoflurane on malignant capability of ovarian cancer in vitro. Br J Anaesth. 2015;114(5): 831-9.

154. Shi QY, Zhang SJ, Liu L, Chen QS, Yu LN, Zhang FJ, Yan M. Sevoflurane promotes the expansion of glioma stem cells through activation of hypoxia-inducible factors in vitro. Br J Anaesth. 2015;114(5):825-30.

155. Semenza GL. Targeting HIF-1 for cancer therapy. Nat Rev Cancer. 2003;3(10): 721-32

156. Liang $H$, Gu M, Yang C, Wang H, Wen X, Zhou Q. Sevoflurane inhibits invasion and migration of lung cancer cells by inactivating the p38 MAPK signaling pathway. J Anesth. 2012;26(3):381-92.

157. Zhang D, Zhou XH, Zhang J, Zhou YX, Ying J, Wu GQ, Qian JH. Propofol promotes cell apoptosis via inhibiting HOTAIR mediated mTOR pathway in cervical cancer. Biochem Biophys Res Commun. 2015;468(4):561-7.

158. Wu KC, Yang ST, Hsu SC, Chiang JH, Hsia TC, Yang JS, Liu KC, Wu RS, Chung JG. Propofol induces DNA damage in mouse leukemic monocyte macrophage RAW264.7 cells. Oncol Rep. 2013;30(5):2304-10.

159. Ye Z, Jingzhong L, Yangbo L, Lei C, Jiandong Y. Propofol inhibits proliferation and invasion of osteosarcoma cells by regulation of microRNA143 expression. Oncol Res. 2013;21(4):201-7.

160. Li Q, Zhang L, Han Y, Jiang Z, Wang Q. Propofol reduces MMPs expression by inhibiting NF-kappaB activity in human MDA-MB-231 cells. Biomed Pharmacother. 2012;66(1):52-6.

161. Liu J, Yang L, Guo X, Jin G, Wang Q, Lv D, Liu J, Chen Q, Song Q, Li B. Sevoflurane suppresses proliferation by upregulating microRNA-203 in breast cancer cells. Mol Med Rep. 2018;18(1):455-60.

162. Fan $L$, Wu Y, Wang J, He J, Han X. Sevoflurane inhibits the migration and invasion of colorectal cancer cells through regulating ERK/MMP-9 pathway by up-regulating miR-203. Eur J Pharmacol. 2019;850:43-52.

163. Yi W, Li D, Guo Y, Zhang Y, Huang B, Li X. Sevoflurane inhibits the migration and invasion of glioma cells by upregulating microRNA-637. Int J Mol Med. 2016;38(6):1857-63.

164. Guo NL, Zhang JX, Wu JP, Xu YH. Isoflurane promotes glucose metabolism through up-regulation of miR-21 and suppresses mitochondrial oxidative phosphorylation in ovarian cancer cells. Biosci Rep. 2017;37(6):BSR20170818.

165. Peng Z, Zhang Y. Propofol inhibits proliferation and accelerates apoptosis of human gastric cancer cells by regulation of microRNA-451 and MMP-2 expression. Genet Mol Res. 2016;15(2).

166. Xu J, Xu W, Zhu J. Propofol suppresses proliferation and invasion of glioma cells by upregulating microRNA-218 expression. Mol Med Rep. 2015;12(4): 4815-20.

167. Zhang J, Zhang D, Wu G-Q, Feng Z-Y, Zhu S-M. Propofol inhibits the adhesion of hepatocellular carcinoma cells by upregulating microRNA-199a and downregulating MMP-9 expression. Hepatobiliary Pancreat Dis Int. 2013;12(3):305-9.
168. Davis DM, SS. Membrane nanotubes: dynamic long-distance connections between animal cells. Nat Rev Mol Cell Biol. 2008;9:431-6.

169. Buschmann D, Brandes F, Lindemann A, Maerte M, Ganschow P, Chouker A, Schelling G, Pfaffl MW, Reithmair M. Propofol and Sevoflurane differentially impact MicroRNAs in circulating extracellular vesicles during colorectal Cancer resection: a pilot study. Anesthesiology. 2020;132(1):107-20.

170. Enlund M, Berglund A, Andreasson K, Cicek C, Enlund A, Bergkvist L. The choice of anaesthetic--sevoflurane or propofol--and outcome from cancer surgery: a retrospective analysis. Ups J Med Sci. 2014;119(3):251-61.

171. Jun IJ, Jo JY, Kim JI, Chin JH, Kim WJ, Kim HR, Lee EH, Choi IC. Impact of anesthetic agents on overall and recurrence-free survival in patients undergoing esophageal cancer surgery: a retrospective observational study. Sci Rep. 2017;7(1):14020.

172. Zheng $X$, Wang Y, Dong L, Zhao S, Wang L, Chen H, Xu Y, Wang G. Effects of propofol-based total intravenous anesthesia on gastric cancer: a retrospective study. Onco Targets Ther. 2018;11:1141-8.

173. Wu ZF, Lee MS, Wong CS, Lu CH, Huang YS, Lin KT, Lou YS, Lin C, Chang YC, Lai HC. Propofol-based Total intravenous anesthesia is associated with better survival than Desflurane anesthesia in Colon Cancer surgery. Anesthesiology. 2018;129(5):932-41.

174. Kim MH, KD, Kim JH, Lee KY, Park S, Yoo YC. Does the type of anesthesia really affect the recurrence-free survival after breast cancer surgery? Oncotarget. 2017:8:90477-87.

175. Oh TK, Kim K, Jheon S, Lee J, Do SH, Hwang JW, Song IA. Long-term oncologic outcomes for patients undergoing volatile versus intravenous anesthesia for non-small cell lung Cancer surgery: a retrospective propensity matching analysis. Cancer Control. 2018;25(1):1073274818775360.

176. Yoo S, Lee HB, Han W, Noh DY, Park SK, Kim WH, Kim JT. Total intravenous anesthesia versus inhalation anesthesia for breast Cancer surgery: a retrospective cohort study. Anesthesiology. 2019;130(1):31-40.

177. Buggy DJ, Borgeat A, Cata J, Doherty DG, Doornebal CW, Forget $P$, Gottumukkala V, Gottschalk A, Gupta A, Gupta K, et al. Consensus statement from the BJA workshop on Cancer and Anaesthesia. Br J Anaesth. 2015; 114(1):2-3.

\section{Publisher's Note}

Springer Nature remains neutral with regard to jurisdictional claims in published maps and institutional affiliations.

Ready to submit your research? Choose BMC and benefit from:

- fast, convenient online submission

- thorough peer review by experienced researchers in your field

- rapid publication on acceptance

- support for research data, including large and complex data types

- gold Open Access which fosters wider collaboration and increased citations

- maximum visibility for your research: over $100 \mathrm{M}$ website views per year

At $\mathrm{BMC}$, research is always in progress.

Learn more biomedcentral.com/submission 